\title{
KEWENANGAN MAHKAMAH KONSTITUSI DALAM PROSES IMPEACHMENT PRESIDEN MENURUT SISTEM KETATANEGARAAN REPUBLIK INDONESIA
}

\author{
Muhammad Fauzan, \\ Fakultas Hukum Universitas) enderal Soedirman Purwokerto \\ E-mail : fauzanhtn@yahoo.co.id
}

\begin{abstract}
The authority of the Constitutional Court to adjudicate and decide upon the opinion of the House of Representatives that the President and/or vice president has violated the law of treason to the state, corruption, bribery, other felonies, or moral turpitude, and/or that the President and / or Vice President no longer meets the conditions as President and/ or Vice President are normative efforts to avoid a repeat of dismisal that are soley based on slander and suspicion which are only to satisfy the political interests of political elites.
\end{abstract}

Key words: The authority of the Constitutional Court, Impeachment

\begin{abstract}
Abstrak
Kewenangan Mahkamah Konstitusi untuk mengadili dan memutus atas pendapat DPR bahwa Presiden dan/atau wakil Presiden telah telah melakukan pelanggaran hukum berupa penghianatan kepada negara, korupsi, penyuapan, tindak pidana berat lainnya, atau perbuatan tercela; dan/ atau pendapat bahwa Presiden dan/atau Wakil Presiden tidak lagi memenuhi syarat sebagai Presiden dan/atau Wakil Presiden adalah merupakan upaya normatif Bangsa Indonesia untuk menghindari terulangnya alasan pemberhentian Presiden dan/ atau Wakil Presiden yang hanya didasarkan kepada fitnah dan sangkaan yang hanya memuaskan kepentingan politik para elit politik.
\end{abstract}

Kata Kunci : Kewenangan MK, Impeachment

\section{Pendahuluan}

Besarnya kekuasaan Presiden dalam UUD 1945 yang disahkan pada tanggal 18 Agustus 1945, memang secara historis dapat "dimakIumi" sebagai salah satu kelemahan UUD 1945 tersebut. Dikatakan dapat dimaklumi, karena sebagaimana diketahui, proses "kelahiran" UUD tersebut diliputi dalam suasana politik yang tidak kondusif sebagai akibat penjajahan, oleh karena itu dilihat dari suasana kebatinan ketika UUD 1945 disahkan sangat diwarnai oleh keinginan para pendiri negara untuk secara cepat memiliki sebuah UUD sebagai salah satu "pegangan" atau guidence dalam menyelenggarakan sistem ketatanegaraan yang baru diproklamirkan sehai sebelumnya, yakni tanggal 17 Agustus 1945.

Ketidaksempurnaan UUD 1945 tersebut juga disadari oleh Ir. Soekarno dalam pidato yang disampaikan pada saat pengesahan UUD 1945 yang intinya dia menyatakan bahwa UUD ini adalah UUD ini adalah UUD kilat yang akan disempurnakan pada saat yang akan datang, jika benar-benar kondisi bangsa dan negara sudah kondusif, atau dalam kondisi benar-benar sudah dalam keadaan "bernegara", karena sifat kesementaraan tersebut, maka pelaksanaan UUD 1945 "diserahkan" pada semangat para penyelenggara negara.

Kesadaran akan kesementaraan UUD 1945 dalam praktiknya tidak dilaksakan sebagaimana mesatinya, bahkan pada masa pemerintahan Presiden Soeharto (Orde Baru) telah menempatkan UUD 1945 laksana seperti "kitab suci" yang diharamkan untuk dilakukan perubahan atasnya. Namun dalam perkembangan selanjutnya sudah menjadi sunatullah dan keniscayaan, bahwa buatan manusia yang disebut sebagai 
UUD 1945 harus berujung pada peruhan juga sebagai dampak tuntutan arus deras reformasi yang salah satu agendanya adalah perubahan UUD 1945.

Keberadaan UUD 1945 sebelum diamandemen yang selama ini disakralkan, dan tidak boleh diubah kini telah mengalami beberapa perubahan. Tuntutan perubahan terhadap UUD 1945 itu pada hakikatnya merupakan tuntutan bagi adanya penataan ulang terhadap kehidupan berbangsa dan bernegara. Atau dengan kata lain sebagai upaya memulai "kontrak sosial" baru antara warga negara dengan negara menuju apa yang dicita-citakan bersama yang dituangkan dalam sebuah peraturan dasar (konstitusi). Perubahan konstitusi ini menginginkan pula adanya perubahan sistem dan kondisi negara yang otoritarian menuju ke arah sistem yang demokratis dengan relasi lembaga negara yang seimbang. Dengan demikian perubahan konstitusi menjadi suatu agenda yang tidak bisa diabaikan. Hal ini menjadi suatu keharusan dan amat menentukan bagi jalannya demokratisasi suatu bangsa. ${ }^{1}$

Beberapa alasan yang melatarbelakangi UUD 1945 harus dirubah antara lain disebabkan karena pertama, UUD 1945 sebelum perubahan melahirkan sistem politik yang executive heavy, menghimpun kekuasaan terlalu besar pada lembaga eksekutif terutama lembaga kepresidenan, dan tidak memuat mekanisme checks and balances; kedua, UUD 1945 sebelum perubahan memuat pasal-pasal yang multi interprateble, berwayuh arti, yang dalam real politiknya interpretasi penguasalah yang harus diterima sebagai interpretasi yang benar; ketiga, UUD 1945 sebelum perubahan terlalu banyak memberi atribusi kewenangan kepada lembaga legislatif untuk mengatur hal-hal penting dengan UU, padahal dengan sistem executive heavy pembuatan UU didominasi oleh presiden sehingga UU menjadi sarana bagi presiden untuk mengakumulasikan kekuasaan; keempat, UUD 1945 sebelum perubahan terlalu

\footnotetext{
Anonimous, Maret 2001, Catatan Catatan-Catatan Terhadap Hasil Rumusan Amandemen Pertama Dan Kedua, Konsorsium Reformasi Hukum Nasional (KRHN), J akarta, hlm. 1.
}

percaya pada semangat dan itikad baik orang yang berkuasa sehingga lebih menguntungkan pada semangat penyelenggara negara dari pada mengatur pembatasan kekuasaan secara tegas ${ }^{2}$

Perubahan UUD 1945 yang telah melalui proses amandemen I sampai ke IV telah membawa perubahan yang sangat fundamental terkait dengan sistem ketatanegaraan Republik Indonesia, eksistensi lembaga negara utama berubah, yakni dengan hilangnya DPA dan lahirnya lembaga negara baru seperti Mahkamah Konstitusi (MK) dan Komisi Yudisial (KY). ${ }^{3}$ MK dianggap sebagai satu kemajuan untuk Indonesia setelah reformasi yakni sebagai pengadilan khusus yang mengadili dan memeriksa pada tingkat pertama dan terakhir untuk kasus pelanggaran UUD, sengketa antar UU dengan UUD, dan sengketa pemilihan umum. ${ }^{4}$

Keberadaan MK sebagai salah satu pelaku kekuasaan kehakiman ${ }^{5}$ dalam sistem ketatanegaraan RI, di samping sebagai konsekuensi dianutnya faham konstitusionalisme dan untuk mempertegas mekanisme check and balances ${ }^{6}$ merupakan salah satu "misi" besar bangsa Indonesia untuk "mempersiapkan" kemungkinan pemberhentian Presiden pada masa jabatannya yang disebabkan karena alasan-alasan hukum yang dalam sejarah katetatanegaraan RI pernah menimpa Presiden Soekarno dan Presiden Ab-

Moh. Mahfud MD, "Perubahan UUD 1945 dan Perkembangan Hukum Tata Negara", J urnal Hukum J urisdictie, Tahun 2010, Jakarta: UIA, hlm. 6. Bandingkan dengan Watiah dan Kusriyah, "Tinjauan Yuridis Hubungan Lembaga Negara antara DPD dengan DPR Dalam Sistem Bicameral di Indonesia", J urnal Hukum Khaira Ummah, Vol. 3 No. 2, September 2008, Semarang: MIH UNISSULA, hlm. 186.

3 Bandingkan dengan Winahyu Erwiningsing, "Mahkamah Konstitusi (Telaah Terhadap Putusan Mahkamah Konstitusi dan Fungsi Mahkamah Konstitusi dalam Reformasi Hukum", Jurnal IImu Hukum, Vol. 9 No. 1, Tahun 2006, Surakarta: Fakultas Hukum UMS, hlm. 89.

4 Usef Fathudin, "UUD 1945 dan Konstitusi Amerika Serikat : Studi Komparatif", SPEKTRA J urnal IImu-IImu Sosial, Vol. 1 No. 1. Tahun 2010, J akarta: Universitas Islam As-Syafi' iyah, hlm. 26.

5 Muhammad Fauzan, "Eksistensi Komisi Yudisial Dalam Struktur Ketatanegaraan Republik Indonesia dan Yang Seharusnya Diatur Dalam Peraturan Perundangundangan", J urnal Dinamika Hukum, Vol. 8 No. 1, Tahun 2008, Purwokerto: Fakultas Hukum UNSOED, hlm. 91.

6 Ali Murtopo, "Peranan mahkamah Konstitusi Dalam Bidang Impeachment Presiden Di Indonesia, J urnal IImu Hukum Novelty, Vol. 3 No. 1, Tahun 2006, Yogyakarta: UAD hlm. 70. 
durrahman Wahid, dan sampai yang bersangkutan meninggal dunia belum ada keputusan hukum (baca: lembaga peradilan) yang menyatakan dia bersalah dan oleh karenanya diturunkan pada masa jabatannya. Dengan perkataan lain, fungsi peradilan dari MK tidak hanya memutus suatu perkara, melainkan juga berfungsi membatasi kekuasaan mayoritas dan mengawasi proses politik agar berjalan di koriidor konstitusi. $^{7}$

Beberapa hal yang melatar belakangi perlunya MK selain "misi" tersebut di atas adalah terkait banyaknya peraturan perundangundangan, khususnya undang-undang yang bertentangan dengan UUD sebagai hukum dasar tertinggi, untuk menyelesaikan kemunginan terjadinya perselisihan kewenangan antara lembaga negara yang kewenangannya diberikan oleh UUD, menghindari kesewenang-wenangan penguasa untuk membubarkan eksistensi partai politik sebagaimana pernah menimpa Partai Masyumi dan Partai Rakyat Demokratik (PRD) serta banyaknya sengketa hasil pemilihan umum pada masa lalu yang tidak jelas penyelesaiannya. Hal tersebut dapat dilihat dari kewenangan yang dimiliki oleh MK sebagaimana dapat dilihat dari ketentuan Pasal 24C UUD 1945 yang menentukan, pertama, Mahkamah Konstitusi berwenang mengadili pada tingkat pertama dan terakhir yang putusannya bersifat final untuk menguji undang-undang terhadap Undang-Undang Dasar, memutus sengketa kewenangan lembaga negara yang kewenangannya diberikan oleh Undang-Undang Dasar, memutus pembubaran partai politik, dan memutus perselisihan tentang hasil pemilihan umum; dan kedua, Mahkamah Konstitusi wajib memberikan putusan atas pendapat Dewan Perwakilan Rakyat mengenai dugaan pelanggaran oleh Presiden dan/atau Wakil Presiden menurut UndangUndang Dasar.

Persoalan yang dapat diketengahkan terkait dengan kewenangan MK tersebut di atas antara lain, mengapa kewenangan-kewenangan tersebut diberikan kepada MK? padahal jika di

Ahmad Syahrizal, "Problematik Implementasi Putusan MK", J urnal Konstitusi, Vol. 4 No. 1, Maret 2007, Jakarta: MKRI hlm. 107 lihat dalam praktik yang selama ini terjadi (baca = sebelum amandemen UUD 1945), undang-undang merupakan produk hukum yang tidak dapat diganggu gugat, kemudian persoalan sengketa kewenangan antar lembaga negara, pembubaran partai politik yang tidak jelas alasannya ${ }^{8}$ dan memutus sengketa hasil pemilihan umum akan selalu "selesai" dengan tidak ada kejelasan, demikian juga terkait dengan Pasal 24C ayat (2) UUD 1945, penyelesaian atas sangkaan Dewan Perwakilan Rakyat (DPR) atas Presiden bahwa Presiden telah melanggar haluan negara selalu diselesaikan melalui lembaga politik dalam hal ini Majelis Permusyawaratan Rakyat (MPR) sebagai lembaga politik?. Atas persoalan tersebut dapat dijelaskan bahwa, terkait dengan judicial review ${ }^{9}$ atas undang-undang terhadap UUD yang menjadi kewenangan $\mathrm{MK}^{10}$ disebabkan karena sebelum amandemen UUD banyak sekali undangundang yang bertentangan dengan semangat UUD namun tidak ada sebuah lembaga atau institusi yang diberi kewenangan untuk melakukan pengujian, hal tersebut menurut penulis sebenarnya disebabkan karena posisi Presiden yang sangat kuat menurut UUD 1945 sebelum diamandemen.

Hal tersebut dapat dilihat dari ketentuan Pasal 5 ayat (1) UUD 1945 sebelum diamandemen yang menentukan bahwa "Presiden memegang kekuasaan membentuk undang-undang dengan persetujuan Dewan Perwakilan Rakyat". Berdasarkan ketentuan tersebut dapat

8 Lihat Muhammad Fauzan, "Pembubaran Partai Politik (Tinjauan Tentang Kewenangan Mahkamah Konstitusi untuk Memutuskan Pembubaran Partai Politik Berasarkan Pasal 24C ayat (1) Undang Undang Dasar 1945)", J urnal Konstitusi PKKKD, 1 (1) Agustus 2008, Malang: FH UMM, hlm. 150.

9 Laica Marjuki, 2007 menyamakan judicial review dengan constitutional review, yakni kewenangan pengujian yang diserahkan kepada lembaga peradilan seperti halnya dengan Supreme Court (USA) dan Constitutional Court, Membangunan Undang Undang Yang Idial, Jurnal Legislasi Indonesia, Vol. 4 No. 2, Tahun 2007, Jakarta: Departemen Hu-kum dan Ham, hlm. 6.

10 Dalam kaitan ini Satjipto Rahardjo menyatakan kekhawatiran tentang kedudukan MK sebagai satu-satunya institusi yang boleh melakukan pengujia terhadap UUD, Lihat Muhammad Fauzan, "Terobosan Mahkamah Konstitusi (Analisis Tentang Putusan MK No. 41/PHPU.DVI/ 2008)", J urnal Dinamika Hukum, Vol. 9 No. 1, J anuari 2009, Purwokerto: Fakultas Hukum UNSOED hlm. 6. 
disimpulkan bahwa pemegang kekuasaan legislatif adalah berada di tangan Presiden, padahal sebagaimana diketahui bahwa kekuasaan legislatif adalah kekuasaan untuk membuat undangundang, dan sebagaimana diketahui juga, bahwa undang-undang adalah produk politik dan oleh karenanya keberadaan sebuah undangundang akan selalu sarat dengan kepentingan politik, dalam hal ini tentunya politik Presiden, artinya bagaimana cara agar sebuah undangundang tidak dapat "diotak atik" keberadaannya. Dengan demikian penulis berpendapat bahwa ketiadaan lembaga negara untuk menguji sebuah undang-undang terhadap UUD lebih disebabkan karena pertimbangan kepentingan politik kekuasaan.

Namun demikian, dalam praktik, keadaan tersebut "dibungkus" secara ilmiah dengan memperkenalkan salah satu asas perundangundangan, yakni "asas undang-undang tidak bisa diganggu gugat", di samping asas-asas yang lain seperti asas hirarki, asas undang-undang tidak berlaku surut, asas undang-undang yang khusus menyampingkan yang umum (lex specialis derograt lex generalis), undang-undang yang baru mengenyampingkan undang-undang lama (lex posteriori de ragraat lex priori). Walaupun jika dikaji dianutnya asas undangundang tidak dapat diganggu gugat, dalam pespektif teoritis tentunya tidak sesuai dengan sistem ketatanegaraan RI yang menempatkan UUD 1945 sebagai produk hukum tertinggi dalam hirarki peraturan perundang-undangan di Indonesia, atau dengan perkataan lain asas undang-undang tidak dapat diganggu gugat tidak dapat dilaksanakan dalam sebuah negara yang menganut paham supremasi konstitusi atau konstitusi derajat tinggi.

Sebagai produk hukum yang secara hirarki menempati kedudukan yang paling tinggi mempunyai konsekuensi bahwa peraturan perundangan yang ada di bawahnya, termasuk di dalamnya undang-undang harus merupakan pelaksanaan lebih lanjut dari UUD, atau dengan perkataan lain tidak boleh bertentangan dengan UUD 1945. Dengan demikian asas undangundang tidak dapat diganggu gugat, hanya tepat dilaksanakan dalam sebuah negara yang sistem hukumnya menempatkan undang-undang sebagai produk hukum yang tertinggi.

Demikian juga terkait dengan sengketa kewenangan antar lembaga negara, pembubaran partai politik dan memutus sengketa hasil pemilihan umum serta penyelesaian atas sangkaan Dewan Perwakilan Rakyat (DPR) atas Presiden bahwa Presiden telah melanggar haluan negara yang selama berlakunya UUD 1945 sebelum diamandemen selalu diselesaikan oleh lembaga politik, dan oleh karenanya putusan yang diambil adalah keputusan politik yang sarat dengan persoalan like and dislike, untuk menghindari hal tersebut, maka kehendak untuk membentuk MK sebagai salah satu pelaksana kekuasaan kehakiman menjadi sangat urgen. Hal tersebut sebagaimana diamanatkan dalam ketentuan Pasal 24 ayat (2) UUD 1945 hasil amandemen yang menentukan bahwa "Kekuasaan kehakiman dilakukan oleh sebuah Mahkamah Agung dan badan peradilan yang berada di bawahnya dalam lingkungan peradilan umum, lingkungan peradilan agama, lingkungan peradilan militer, lingkungan peradilan tata usaha negara, dan oleh sebuah Mahkamah Konstitusi".

Tulisan ini berusaha untuk menganalisis persoalan yang terkait dengan pemberhentian Presiden dalam masa jabatannya (impeachment) sebagaimana diamanatkan dalam Pasal 24C ayat (2) UUD 1945 hasil amandemen yang menentukan: Mahkamah Konstitusi wajib memberikan putusan atas pendapat Dewan Perwakilan Rakyat mengenai dugaan pelanggaran oleh Presiden dan/atau Wakil Presiden menurut Undang-Undang Dasar.

\section{Pembahasan \\ Pengertian dan Sejarah Impeachment}

Persoalan impeachment atau yang secara etimologis berarti pendakwaan, atau tuduhan atau Panggilan untuk melakukan pertanggunggjawaban. ${ }^{11}$ Dan juga dapat berarti pemanggilan atau pendakwaan untuk meminta pertanggungjawaban atas persangkaan pelanggaran hukum yang dilakukan oleh Presiden dan/atau

11 Sapuan, 2010 Impeachment Presiden, Purwokerto: STAIN Press, hlm. 56. 
Wakil Presiden dalam masa jabatannya, ${ }^{12}$ dalam sejarah penyelenggaraan pemerintahan Indonesia baru memperoleh "bentuk" nya setelah Undang Undang Dasar (UUD) 1945 diamandemen.

Black's Law Dictionary mendefinisikan impeachment sebagai "A criminal proceeding against a publik officer, before a quasi political court, instituted by a written accusation called "articles of impeachment". Impeachment diartikan sebagai suatu proses peradilan pidana terhadap seorang pejabat publik yang dilaksanakan dihadapan senat atau disebut dengan quasi political court. Suatu proses impeachment dimulai dengan adanya article of impeachment yang berfungsi sama dengan surat dakwaan dari suatu peradilan pidana. Jadi article of impeachment adalah satu surat resmi yang berisi tuduhan yang menyebabkan dimulainya suatu proses impeachment. ${ }^{13}$

Berdasarkan uraian tersebut, maka jika dikaitkan dengan eksistensi Presiden, dapat disimpulkan bahwa yang dimaksud dengan impeachment adalah proses pemanggilan atau pendakwaan yang dilakukan oleh lembaga legislatif kepada pejabat publik (baca= Presiden/ Kepala Pemerintahan) untuk dimintai pertanggungjawaban atas persangkaan pelanggaran hukum yang dilakukan dalam masa jabatannya.

Berdasarkan perspektif sejarah ketatanegaraan dan peradaban dunia impeachment lahir pada zaman Mesir Kuno dengan istilah "iesangelia" yang berarti "kecenderungan ke arah pengasingan diri" yang diadopsi oleh pemerintahan Inggris pada abad ke 17 dan dimasukkan ke dalam konstitusi Amerika Serikat pada abad ke $18 .{ }^{14}$

Impeachment berasal dari praktik ketatanegaraan bangsa Inggris pada abad ke 14 pada masa pemerintahan Edward III. Kasus impeach-

12 J imly Asshiddiqie, http:// www.theceli.com// pub/files/ IMPEACHMENT. doc.

13 Winarno Yudho, dkk, 2005, Mekanisme Impeachment dan Hukum Acara Mahkamah Konstitusi, J akarta: Konrad Adenauer Stiftung dan Pusat Penelitian dan Pengkajian Sekretariat Jenderal dan Kepaniteraan Mahkamah Konstitusi Republik Indonesia, hlm. 6.

14 Abdul Rasyid Thalib, 2006, Wewenang Mahkamah Konstitusi dan Implikasinya dalam Sistem Ketatanegaraan Indonesia, Bandung: Citra Aditya Bakti, hlm. 24. ment pertama kali pada bulan Nopember 1330 di mana The House of Common yang bertindak sebagai a Grand Jury telah melakukan impeachment terhadap Roger Mortimer, Baron of Wigmore ke VIII dan Earl of March dan lembaga yang memutus perkara tersebut adalah The House Of Lord. ${ }^{15}$ Bangsa Inggris mengembangkan sistem tersebut di negara jajahannya termasuk dikembangkan Amerika Serikat pada abad ke 17 yang justru pada perkembangannya impeachment tersebut lebih dikenal di negara Amerika Serikat. Proses impeachment pada waktu itu dilakukan untuk memproses pejabatpejabat tinggi dan individu-individu yang sangat berkuasa pada bangsa Inggris dan Amerika Serikat yang mempunyai kecenderungan menyalahgunakan kekuasaannya sehingga tindakan yang dilakukan tidak tersentuh lembaga pengadilan biasa. Selain itu, juga untuk menciptakan sistem checks and balances sehingga proses impeachment digunakan sebagai alat untuk membatasi perbuatan-perbuatan penguasa negara yang menyimpang dan mencederai kepercayaan publik. ${ }^{16}$

Impeachment diperlukan dalam rangka menjaga agar penguasa atau dalam hal ini Presiden selalu bertindak dan sesuai dengan koridor hukum yang telah disepakati bersama, oleh karena itu impeachment tidak lain merupakan salah satu kontrol yang dimiliki oleh lembaga legislatif untuk selalu mengawasi Presiden dalam penyelenggaraan pemerintahan. Dengan demikian jika lembaga legislatif dalam hal ini DPR melihat pemegang kekuasaan negara tersebut melakukan pelanggaran hukum, maka dengan amanat yang telah diberikan oleh rakyat untuk melakukan fungsi kontrol tersebut, dapat melakukan proses impeachment.

\section{Pemberhentian Presiden dalam Sistem Ketatanegaraan Republik Indonesia}

Ada dua perspektif hukum ketatanegaraan (constitutional law) dalam cara pemberhentian Presiden dan/ atau Wakil Presiden. Pertama, dengan cara impeachment dan kedua,

15 Ibid., hlm. 5.

16 Sapuan, op.cit., hlm. 46. 
dengan cara pemberhentian melalui mekanisme forum peradilan khusus (special legal proceeding) atau forum "privelegiatum" yaitu forum peradilan khusus diadakan untuk itu. ${ }^{17}$

Pemberhentian Presiden melalui "impeachment" dalam sejarah ketatanegaraan RI terjadi ketika Presiden Soekarno diberhentikan dari jabatan sebagai Presiden dalam masa jabatannya yang dilakukan oleh MPRS dengan Tap. MPRS No. XXXIII/MPRS/ 1967 dan Presiden Abdurrahman Wahid yang didasarkan pada Tap. MPR Nomor VII Tahun 1973 dan Tap. MPR Nomor III Tahun 1978. Sedangkan pemberhentian dengan cara Special legal proceeding atau forum prevelegiatum, yaitu pemberhentian Presiden dan/atau Wakil Presiden melalui proses peradilan yang khusus diadakan untuk keperluan yang putusannya bersifat final dan mengingat guna mengadili Presiden dan/atau Wakil Presiden dan oleh karena itu peran lembaga legislatif sama sekali tidak ada dlam pemberhentian dengan cara special legal proceeding .

Model special legal proceeding ini pernah dianut dalam Pasal 106 Undang-undang Dasar Sementara (UUDS) Tahun 1950 yang menentukan bahwa: Presiden dan Pejabat Tinggi Negara lainnya dapat diadili pada tingkat pertama dan terakhir di Mahkamah Agung karena kejahatan, pelanggaran jabatan, dan pelanggaran lainnya yang ditetapkan dengan undang-undang. Dalam perspektif UUD 1945 sebelum diamandemen, mekanisme pertanggungjawaban Presiden pada masa jabatannya sama sekali tidak diatur. Pasal 6 ayat (2) UUD 1945 hanya menentukan bahwa Presiden dan Wakil Presiden dipilih oleh Majelis Permusyawaratan Rakyat dengan suara yang terbanyak. Kemudian Pasal 7 menentukan bahwa Presiden dan Wakil Presiden memegang jabatannya selama masa lima tahun, dan sesudahnya dapat dipilih kembali.

Secara tegas UUD 1945 sebelum diamandemen tidak mengatur mekanisme pemberhentian Presiden dan/atau Wakil Presiden dalam masa jabatannya, hal tersebut sebagai konsekuensi dianutnya sistem pemerintahan sistem pemerintahan Presidensiil. Di mana dalam sistem pemerintahan presidensiil jabatan Presiden adalah fix, oleh karena itu pemberhentian Presiden dalam masa jabatannya sekalipun bisa dilakukan hanya disebabkan karena hal-hal yang sangat luar biasa, seperti misalnya Presiden telah secara nyata melakukan penghianatan terhadap negara dan lainlain.

Memperhatikan uraian tersebut, maka dapat dipahami jika UUD 1945 sebelum di amandemen sebagaimana telah diuraikan di atas, memberikan kekuasaan Presiden "sangat" besar, dan karena begitu besarnya kekuasaan Presiden sampai dibuat norma yang menjadi materi muatan UUD yang tidak memberikan "peluang" Presiden untuk diberhentikan di dalam masa jabatannya.

Memang dalam UUD 1945 sebelum diamandemen pemberhentian Presiden dan/atau Wakil Presiden dalam masa jabatannya tidak diatur, namun hal tersebut bukanlah sesuatu yang sulit dilaksanakan sebab hal tersebut merupakan konsekuensi kewenangan untuk memilih Presiden dan Wakil Presiden oleh MPR juga berati kewenangan untuk memberhentikan Presiden dan/ atau Wakil Presiden ada di tangan MPR. Dengan demikian, sepanjang MPR mempunyai keinginan untuk memberhentikan seorang Presiden dan/ atau Wakil Presiden, maka hal tersebut dapat dilakukan, terlebih kedudukan Presiden dalam sistem ketatanegaraan RI ketika itu adalah sebagai mandataris MPR, oleh karena itu MPR sebagai pemberi mandat dapat menarik kembali mandatnya dari tangan Presiden/mandataris.

Menurut sistem pemerintahan presidensiil Presiden dan/ atau Wakil Presiden berkedudukan kuat dan tidak dapat dijatuhkan oleh parlemen, bahwa dalam sejarah penyelengaraan kehidupan ketatanegaraan Republik Indonesia pernah terjadi seorang Presiden "diberhentikan" pada masa jabatannya, lebih disebabkan karena penafsiran terhadap UUD 1945, sekalipun dalam Penjelasan UUD 1945 pemberhentian Presiden pada masa jabatannya juga tidak ditemukan secara tekstual/ implisit.

17 Abdul Rasyid Thalib, loc. cit. 
Pemberhentian Presiden dan/atau Wakil Presiden yang pernah terjadi dalam kasus pemberhentian Presiden Soekarno dan Presiden Abdurahman Wahid sebanarnya merupakan kreativitas para elit politik dengan memberikan penafsiran atas Penjelasan UUD 1945. Dalam Penjelasan UUD 1945 dinyatakan bahwa: “Majelis ini mengangkat Kepala Negara (Presiden) dan Wakil Kepala Negara (Wakil Presiden). Majelis inilah yang memegang kekuasaan negara yang tertinggi, sedang Presiden harus menjalankan haluan negara menurut garisgaris besar yang ditetapkan oleh Majelis. Presiden yang diangkat oleh Majelis, bertunduk dan bertanggung jawab kepada Majelis. la ialah "mandataris" dari Majelis. la berwajib menjalankan putusan-putusan Majelis." Pada bagian Iain Penjelasan UUD 1945 juga dinyatakan bahwa "...DPR dapat senantiasa mengawasi tindakan-tindakan Presiden dan jika Dewan menganggap bahwa Presiden sungguh melanggar haluan negara yang telah ditetapkan oleh UUD atau oleh MPR, maka MPR itu dapat diundang untuk persidangan istimewa agar supaya bisa minta pertanggungan jawab kepada Presiden. ${ }^{18}$

Berdasarkan ketentuan tersebut, maka bagaimana mekanisme pemberhentian dibutuhkan pengaturan, namun dalam perjalanan sistem katetanegaraan RI ternyata mekanisme pemberhentian Presiden pada masa jabatannya tidak pernah diatur dan menjadi materi muatan UUD, paling tidak sampai UUD 1945 diamandemen. Mekanisme pemberhentian seorang Presiden hanya menjadi materi muatan Ketetapan MPR, yakni dalam Tap MPR RI No. VII/ MPR/ 1973 dan Tap MPR No. III/ MPR/ 1978.

Berdasarkan ketentuan Pasal 4 Tap MPR No. III/MPR/ 1978 tersebut MPR dapat memberhentikan Presiden sebelum habis masa jabatannya dengan alasan: (1). Atas permintaan sendiri; (2). Berhalangan tetap; dan (3). Sungguhsungguh melanggar haluan negara. Dalam Pasal 5 Tap MPR No. III/MPR/ 1978 digariskan bahwa Presiden tunduk dan bertanggungjawab kepada

18 Lihat Penjelasan UUD 1945, Sebelum UUD 1945 diamandemen, UUD 1945 merupakan satu kesatuan yang terdiri dari Pembukaan, batang Tubuh dan Penjelasan.
MPR dan pada akhir masa jabatannya memberikan pertanggungjawaban atas pelaksanaan haluan negara yang ditetapkan oleh UUD atau MPR di hadapan sidang MPR; dan Presiden wajib memberikan pertanggungjawaban di hadapan Sidang Istimewa MPR yang khusus diadakan untuk meminta pertanggungjawaban presiden dalam pelaksanaan haluan negara yang ditetapkan oleh UUD atau MPR. Dalam perkembangannya ketentuan tersebut dikuatkan kembali dalam Ketetapan MPR RI No. II/MPR/ 2000 tentang Perubahan Kedua Atas Ketetapan MPR RI Nomor II/MPR/ 1999 tentang Peraturan Tata Tertib MPR.

Salah satu momen ketatanegaraan sebagaimana telah disebutkan atas terkait dengan pemberhentian Presiden pada masa jabatannya yang terakhir terjadi pada saat kekuasaan pemerintahan negara dijabat oleh Presiden Abdurrahman Wahid. Proses pemberhentian Abdurrahman Wahid berawal dari tuduhan keterlibatannya dalam kasus Yanatera Bulog dan dana bantuan dari Sultan Brunei Darussalam. Tuduhan tersebut direspon oleh DPR dengan mangajukan usul penggunaan hak mengadakan penyelidikan yang disetuj ui dalam Rapat Paripurna DPR pada tanggal 28 Agustus 2000 dan ditindaklanjuti dengan pembentukan Panitia Khusus (Pansus) yang dibentuk pada tanggal 5 September 2000.

Sebagaimana sudah dapat diduga sebelumnya, akhirnya Pansus menyimpulkan bahwa Presiden Abdurrahman Wahid "patut diduga" terlibat di dalam kedua kasus Brubei Gate dan Bulog Gate dan berdasarkan Keputusan DPR RI Nomor 33/ DPR RI/ III/ 2000-2001, tanggal 1 Februari 2001 tentang Penetapan Memorandum DPR RI kepada Abdurrahman Wahid untuk mengingatkan bahwa Presiden Abdurrahman Wahid telah dengan sungguh-sungguh telah melanggar Haluan Negara yaitu (a) Melanggar ketentuan Pasal 9 UUD 1945 tentang Sumpah J abatan; dan (b) Melanggar Ketetapan MPR RI Nomor XI/ MPR/ 1998 tentang Penyelenggaraan Negara yang Bersih dan Bebas KKN.

Peristiwa ketatanegaraan tersebut telah menjadi bukti bahwa Tap MPR No. VII/MPR/ 1973 jo Tap MPR No. III/MPR/ 1978 yang men- 
jadi dasar pemberhentian Presiden pada masa jabatannya telah membawa "korban". Dikatakan korban karena pemberhentian Presiden Abdurrahman Wahid yang dimulai dari issue korupsi dana dari Sultas Brunei Darussalam yang kemnudian dikenal dengan Bruneigate dan korupsi dana non budgeter Bulog yang dikenal dengan Buloggate dan oleh karenanya merupakan persoalan hukum, namun diselesaikan melalui mekanisme politik dan berujung pada pemberhentian Presiden Abdurrahman Wahid telah meninggalkan "perdebatan", dan bahkan sampai akhir hayatnya mantan Presiden Abdurrahman Wahid menganggap bahwa pemberhentian dirinya adalah inkonstitusional, dan di kalangan ahli hukum tata negara juga muncul bahwa pemberhentian tersebut tidak sah.

Bahkan sebelum peristiwa pemberhentian Presiden Abdurrahman Wahid terjadi, Moh. Mahfud MD sebagai Menteri Pertahanan dan kebetulan juga berlatar belakang sebagai akademisi yang mempunyai keahlian dalam bidang hukum tata negara, berjuang "mati-matian" agar Presiden Abdurrahman Wahid tidak diberhentikan karena alasan yang disangkakan kepadanya sarat dengan kepentingan politik, sekalipun starting pointnya dari sangkaan bahwa Presiden telah melakukan korupsi dana nonbudgeter dan menerima dana tidak sah dari pihak asing, yang sebenarnya merupakan persoalan hukum, oleh karenanya mestinya dibuktikan dulu dalam lembaga peradilan, baru kemudian jika kelak terbukti bahwa Presiden salah, dan karenanya dipidana, maka proses pemberhentian selanjutnya tidak menjadi persoalan buat pribadi Presiden Abdurrahman Wahid.

Kuatnya nuansa politis tersebut sehingga sampai sekarang masih menyisakan problem konstitusional maupun problem konseptual. Problem konstitusional ini terlihat: pertama, Soekarno dan Abdurrahman Wahid tidak terbukti secara sah dan meyakinkan telah melakukan pelanggaran terhadap ketentuan UUD 1945; kedua, ketentuan hukum yang digunakan oleh MPRS atau MPR (MPR/S) sebagai dasar pemberhentian untuk memberhentikan keduanya tidak didasarkan pada ketentuan yang diatur secara tegas di dalam UUD 1945; ketiga, pemberhentian tersebut dituangkan dalam Tap. MPR yang di dalam Hierarkhi sumber tertib hukum berada di bawah UUD 1945.

Untuk menghindari terulangnya pemberhentian Presiden pada masa jabatannya karena lebih disebababkan alasan-alasan politis, maka Amandemen UUD 1945 memperkenalkan lembaga negara baru, yakni Mahkamah Konstitusi (MK). Eksistensi Mahkamah Konstitusi ditandai dengan disahkannya ketentuan Pasal 24 ayat (2) dan Pasal 24C UUD 1945 yang menjadi bagian Perubahan Ketiga UUD 1945 pada Sidang Tahunan MPR 2001 tanggal 9 November 2001. Disahkannya pasal tersebut, maka Indonesia menjadi negara ke-78 yang membentuk MK dan menjadi negara pertama pada abad ke-21 yang membentuk lembaga kekuasaan kehakiman tersebut.

Pasal 24 ayat (2) UUD 1945 menyatakan: Kekuasaan kehakiman dilakukan oleh sebuah Mahkamah Agung dan badan peradilan yang berada di bawahnya dalam lingkungan peradilan umum, lingkungan peradilan agama, lingkungan peradilan militer, lingkungan peradilan tata usaha negara, dan oleh sebuah Mahkamah Konstitusi. Eksistensi Mahkamah Konstitusi (MK) diawali dengan diadopsinya ide MK (Constitutional Court) dapat dilihat dengan jelas dalam ketentuan Pasal 24 ayat (2), Pasal 24C, dan Pasal 7B UUD 1945 hasil amandemen ketiga yang disahkan pada 9 Nopember 2001.

Sesuai dengan ketentuan Pasal III Aturan Peralihan UUD 1945 hasil amandemen keempat yang mengamanatkan bahwa Mahkamah Konstitusi dibentuk selambat-lambatnya pada 17 Agustus 2003 dan sebelum dibentuk segala kewenangannya dilakukan oleh Mahkamah Agung. Memperhatikan ketentuan tersebut, maka dalam rangka menunggu realisasi terbentuknya MK, segala kewenagan dan fungsi MK dilaksanakan oleh MA.

Eksistensi MK dalam sistem ketatanegaraan Indonesia diatur lebih lanjut dalam Undang-Undang (UU) Nomor 24 Tahun 2003 tentang Mahkamah Konstitusi yang disahkan pada 13 Agustus 2003 oleh Presiden dan dimuat da- 
Iam Lembaran Negara Nomor 98 dan Tambahan Lembaran Negara Nomor 4316. Dan pada tanggal 15 Agustus 2003, Presiden melalui Keputusan Presiden Nomor 147/M Tahun 2003 hakim konstitusi untuk pertama kalinya yang dilanjutkan dengan pengucapan sumpah jabatan para hakim konstitusi di Istana Negara pada tanggal 16 Agustus 2003. Operasional MK ditandai dengan adanya pelimpahan kewenangan oleh MA pada tanggal 15 Oktober 2003 sebagai salah satu cabang kekuasaan kehakiman menurut ketentuan UUD 1945.

UU No. 24 Tahun 2003 tentang Mahkamah Konstitusi dimana Pasal 10 menentukan kewenangan MK sebagai berikut. Pertama, menguji undang-undang terhadap Undang-Undang Dasar Negara Republik Indonesia Tahun 1945; kedua, memutus sengketa kewenangan lembaga negara yang kewenangannya diberikan oleh Undang-Undang Dasar Negara Republik Indonesia Tahun 1945; ketiga, memutus pembubaran partai politik; keempat, memutus perselisihan tentang hasil pemilihan umum; dan kelima, Mahkamah Konstitusi wajib memberi putusan atas pendapat DPR bahwa Presiden dan/atau Wakil Presiden diduga telah melakukan pelanggaran hukum berupa penghianatan terhadap negara, korupsi, penyuapan, tindak pidana berat lainnya, atau perbuatan tercela, dan/atau tidak lagi memenuhi syarat sebagai Presiden dan/atau Wakil Presiden sebagaimana dimaksud dalam Undang-Undang Dasar Negara Republik Indonesia Tahun 1945.

Setalah UUD 1945 diamandemen, maka pemberhentian Presiden pada masa jabatannya dapat dilihat dalam ketentuan Pasal 3 ayat (3) UUD 1945 hasil amandemen yang berbunyi: "MPR hanya dapat memberhentikan Presiden dan/atau Wakil Presiden dalam masa jabatannya menurut Undang-Undang Dasar (UUD)".

Selain itu juga diatur di dalam ketentuan pasal 7A dan 7B UUD 1945. Ketentuan pasal 7A UUD 1945 yang menentukan bahwa "Presiden dan/atau Wakil Presiden dapat diberhentikan dalam masa jabatannya oleh MPR atas usul DPR, baik apabila terbukti telah melakukan pelanggaran hukum berupa penghianatan terhadap negara, korupsi, penyuapan, tindak pi- dana berat lainnya, atau perbuatan tercela maupun apabila terbukti tidak lagi memenuhi syarat sebagai Presiden dan/atau Wakil Presiden".

Mekanisme yang harus ditempuh dalam memberhentikan Presiden dan/atau Wakil Presiden telah diataur dalam Pasal 7B UUD 1945 yang secara garis besar menentukan beberapa tahapan yang harus dilewati. Pertama, usul pemberhentian Presiden dan/atau Wakil Presiden dapat diajukan oleh Dewan Perwakilan Rakyat kepada Majelis Permusyawaratan Rakyat hanya dengan terlebih dahulu mengajukan permintaan kepada Mahkamah Konstitusi untuk memeriksa, mengadili dan memutus pendapat Dewan Perwakilan Rakyat bahwa Presiden dan/ atau Wakil Presiden telah melakukan pelanggaran hukum berupa penghianatan kepada negara, korupsi, penyuapan, tindak pidana berat lainnya, atau perbuatan tercela; dan/atau pendapat bahwa Presiden dan/atau Wakil Presiden tidak lagi memenuhi syarat sebagai Presiden dan/ atau Wakil Presiden.

Kedua, pendapat Dewan Perwakilan Rakyat bahwa Presiden dan/atau Wakil Presiden telah melakukan pelanggaran hukum tersebut ataupun telah tidak lagi memenuhi syarat sebagai Presiden dan/atau Wakil Presiden adalah dalam rangka pelaksanaan fungsi pengawasan Dewan Perwakilan Rakyat. Ketiga, pengajuan permintaan Dewan Perwakilan Rakyat kepada Mahkamah Konstitusi hanya dapat dilakukan dengan dukungan sekurang-kurangnya 2/3 dari jumlah anggota Dewan Perwakilan Rakyat yang hadir dalam sidang paripurna yang dihadiri oleh sekurang-kurangnya 2/ 3 dari jumlah anggota Dewan Perwakilan Rakyat.

Keempat, Mahkamah Konstitusi wajib memeriksa, mengadili dan memutus dengan seadil-adilnya terhadap pendapat Dewan Perwakilan Rakyat tersebut paling lama sembilan puluh hari setelah permintaan Dewan Perwakilan Rakyat itu diterima oleh Mahkamah Konstitusi. Kelima, apabila Mahkamah Konstitusi memutus bahwa Presiden dan/atau Wakil Presiden terbukti melakukan pelanggaran hukum berupa penghianatan terhadap negara, korupsi, penyuapan, tindak pidana berat lain- 
nya, atau perbuatan tercela; dan/ atau terbukti bahwa Presiden dan/ atau Wakil Presiden tidak lagi memenuhi syarat sebagai Presiden dan/ atau Wakil Presiden, Dewan Perwakilan Rakyat menyelenggarakan sidang paripurna untuk meneruskan usul pemberhentian Presiden dan/ atau Wakil Presiden kepada Majelis Permusyawaratan Rakyat.

Keenam, Majelis Permusyawaratan Rakyat wajib menyelenggarakan sidang untuk memutuskan usul Dewan Perwakilan Rakyat tersebut paling lambat tiga puluh hari sejak Majelis Permusyawaratan Rakyat menerima usul tersebut. Ketujuh, Keputusan Majelis Permusyawaratan Rakyat atas usul pemberhentian Presiden dan/ atau Wakil Presiden harus diambil dalam rapat paripurna Majelis Permusyawaratan Rakyat yang dihadiri oleh sekurang-kurangnya $2 / 3$ dari jumlah anggota yang hadir, setelah Presiden dan/atau Wakil Presiden diberi kesempatan menyampaikan penjelasan dalam rapat paripurna Maj elis Permusyawaran Rakyat.

Berdasarkan uraian tersebut, maka dapat dikatakan bahwa mekanisme pemberhentian seorang Presiden dan/atau Wakil Presiden hanya dapat dilakukan melalui mekanisme hukum due process of law. Kemudian berdasarkan ketentuan Pasal 7B ayat (4) UUD 1945 MK wajib memeriksa, mengadili dan memutus dengan seadil-adilnya terhadap pendapat Dewan Perwakilan Rakyat paling lama sembilan puluh hari setelah permintaan Dewan Perwakilan Rakyat itu diterima oleh Mahkamah Konstitusi.

\section{Mekanisme Impeacment Presiden di Mahka- mah Konstitusi}

Proses impeachment pada dasarnya merupakan salah satu pelaksanaan fungsi kontrol atau pengawasan ${ }^{19}$ yang dimiliki oleh DPR agar dalam melaksanakan tugas dan kewenangannya Presiden dan/atau Wakil Presiden melaksana-

19 Lihat ketentuan Pasal 7B ayat (2) yang menentukan bahwa Pendapat Dewan Perwakilan Rakyat bahwa Presiden dan/atau Wakil Presiden telah melakukan pelanggaran hukum tersebut ataupun telah tidak lagi memenuhi syarat sebagai Presiden dan/atau Wakil Presiden adalah dalam rangka pelaksanaan fungsi pengawasan Dewan Perwakilan Rakyat. kan hal-hal yang dapat mengakibatkan seorang Presiden dan/atau Wakil Presiden diberhentikan dalam masa jabatannya sebagaimana diatur dalam ketentuan Pasal 7B ayat (1) UUD hasil amandemen, seperti melakukan pelanggaran hukum berupa pengkhianatan terhadap negara, korupsi, penyuapan, tindak pidana berat lainnya, atau perbuatan tercela; dan/atau pendapat bahwa Presiden dan/atau Wakil Presiden tidak lagi memenuhi syarat sebagai Presiden dan/ atau Wakil Presiden.

Atas pendapat DPR bahwa Presiden dan/ atau Wakil Presiden telah melakukan pelanggaran hukum dan/atau tidak lagi memenuhi syarat sebagai Presiden dan/atau Wakil Presiden, maka berdasarkan ketentuan Pasal 24C ayat (1) UUD 1945 hasil amandemen sebagaimana telah diuraikan di atas, lembaga negara yang diberi kewenangan untuk memeriksa dan memutus persoalan tersebut adalah MK. Untuk keperluan tersebut, maka MK me-ngeluarkan PMK No. 21 Tahun 2009 tentang Pedoman Beracara Dalam Memutus Pendapat DPR Mengenai Dugaan Pelanggaran Oleh Presiden dan/ Wakil Presiden.

Beberapa hal yang perlu diperhatikan dari PMK No. 21 Tahun 2009 adalah (1) Pihak yang berperkara; (2) Tata Cara Pengajuan Permohonan; (3) Registrasi Perkara dan Penjadualan Sidang; dan (4) Persidangan.

Berdasarkan ketentuan Pasal 2 ayat 1 PMK No. 21 tahun 2009 tentang Pedoman Beracara Dalam Memutus Pendapat DPR Mengenai Dugaan Pelanggaran Oleh Presiden dan/ Wakil Presiden ditentukan bahwa Pihak yang memohon putusan mahkamah atas pendapat DPR adalah DPR yang diwakili oleh pimpinan DPR yang dapat menunjuk kuasa hukumnya. Memperhatikan hal tersebut, maka palaksanaan pengajuan hanya dapat dilakukan oleh Pimpinan DPR atau kuasa hukumnya, dengan demikian maka anggota DPR baik atas nama pribadi atau kelompok anggota DPR yang tergabung dalam fraksi, tidak dapat mengajukan permohonan putusan kepada Mahkamah atas adanya pendapat DPR sebagaimana diuraikan di atas. Sedangkan pihak termohon berdasarkan ketentuan Pasal 2 ayat (2) PMK No.21 Tahun 2009 
adalah Presiden dan/ atau Wakil Presiden yang dapat didampingi dan/atau diwakili oleh kuasa hukumnya.

Tata cara pengajuan permohonan agar MK memutus pendapat DPR bahwa Presiden dan/atau Wakil Presiden telah melakukan pelanggaran hukum dan atau telah tidak memenuhi persyaratan sebagai Presiden dan/atau Wakil Presiden diatur dalam Bab III PMK No. 21 Tahun 2009 yang secara garis besar dapat disimpulkan sebagai berikut. Pertama, permohonan kepada MK harus diajukan oleh pimpinan DPR atau kuasanya secara tertulis dalam Bahasa Indonesia dan dibuat 12 rangkap yang ditandatangani oleh Pimpinan DPR atau kuasa hukumya.

Kedua, dalam surat permohonan kepada MK tersebut DPR wajib menguraikan dengan jelas mengenai dugaan bahwa Presiden dan/ atau Wakil Presiden telah melakukan pelanggaran hukum berupa pengkhiantan terhadap negara, korupsi, penyuapan, tindak pidana berat lainnya, atau perbuatan tercela; dan apakah Presiden dan/atau Wakil Presiden juga tidak lagi memenuhi syarat sebagai Presiden dan/atau Wakil Presiden berdasarkan UUD 1945.

Berdasarkan ketentuan Pasal 1 PMK No.

21 Tahun 2009 diuraikan bahwa yang dimaksud dengan pelanggaran hukum yang berupa penghianatan terhadap negara, korupsi, penyuapan, tindak pidana berat lainnya dan perbuatan tercela. Pengkhianatan terhadap Negara adalah tindak pidana terhadap keamanan Negara sebagaimana diatur dalam Undang-Undang. Dengan demikian Presiden dan/atau Wakil Presiden yang diduga melakukan korupsi apabila yang bersangkutan melakukan tindak pidana sebagaimana diatur dalam UU No. 20 tahun 2001 tentang Perubahan atas Undang-undang nomor 31 tahun 1999 tentang Pemberantasan Tindak Pidana Korupsi, yakni perbuatan yang secara melawan hukum memperkaya diri sendiri atau orang lain atau suatu korporasi yang dapat merugikan keuangan atau perekonomian negara.

Demikian juga yang dimaksud dengan penyuapan adalah tindak pidana penyuapan se- bagaimana diatur dalam Undang-Undang. Sedangkan Tindak pidana berat lainnya adalah tindak pidana yang diancam dengan pidana penjara 5 (lima) tahun atau lebih dan perbuatan tercela adalah perbuatan yang dapat merendahkan martabat Presiden dan/atau Wakil Presiden. Terakhir adalah yang dimaksud dengan tidak lagi memenuhi syarat sebagai Presiden dan/ atau Wakil Presiden adalah syarat sebagaimana ditentukan dalam Pasal 6 UUD 1945 dan Undang-Undang yang terkait. UU yang menentukan tentang persyaratan Presiden dan atau Wakil Presiden dapat dilihat dalam UU No. 42 Tahun 2008 tentang Pemilihan Umum Presiden dan Wakil Presiden.

Berdasarkan ketentuan Pasal 5 UU No. 42 Tahun 2008 ditentukan bahwa syarat-syarat yang harus dipenuhi oleh calon Presiden dan Wakil Presiden meliputi: bertakwa kepada Tuhan Yang Maha Esa; warga Negara Indonesia sejak kelahirannya dan tidak pernah menerima kewarganegaraan lain karena kehendaknya sendiri; tidak pernah mengkhianati negara, serta tidak pernah melakukan tindak pidana korupsi dan tindak pidana berat lainnya; mampu secara rohani dan jasmani untuk melaksanakan tugas dan kewajiban sebagai Presiden dan Wakil Presiden; bertempat tinggal di wilayah Negara Kesatuan Republik Indonesia; telah melaporkan kekayaannya kepada instansi yang berwenang memeriksa laporan kekayaan penyelenggara negara; tidak sedang memiliki tanggungan utang secara perseorangan dan/atau secara badan hukum yang menjadi tanggung jawabnya yang merugikan keuangan negara; tidak sedang dinyatakan pailit berdasarkan putusan pengadilan; tidak pernah melakukan perbuatan tercela; terdaftar sebagai Pemilih; memiliki Nomor Pokok Wajib Pajak (NPWP) dan telah melaksanakan kewajiban membayar pajak selama 5 (lima) tahun terakhir yang dibuktikan dengan Surat Pemberitahuan Tahunan Pajak Penghasilan Wajib Pajak Orang Pribadi; belum pernah menjabat sebagai Presiden atau Wakil Presiden selama 2 (dua) kali masa jabatan dalam jabatan yang sama; setia kepada Pancasila sebagai dasar negara, Undang-Undang Dasar Negara Republik Indonesia Tahun 1945, dan cita-cita 
82 J urnal Dinamika Hukum

Vol. 11 No. 1 J anuari 2011

Proklamasi 17 Agustus 1945; tidak pernah dijatuhi pidana penjara berdasarkan putusan pengadilan yang telah mempunyai kekuatan hukum tetap karena melakukan tindak pidana yang diancam dengan pidana penjara 5 (lima) tahun atau lebih; berusia sekurang-kurangnya 35 (tiga puluh lima) tahun; berpendidikan paling rendah tamat Sekolah Menengah Atas (SMA), Madrasah Aliyah (MA), Sekolah Menengah Kejuruan (SMK), Madrasah Aliyah Kejuruan (MAK), atau bentuk lain yang sederajat; bukan bekas anggota organisasi terlarang Partai Komunis Indonesia, termasuk organisasi massanya, atau bukan orang yang terlibat langsung dalam G. 30.S/ PKI; dan memiliki visi, misi, dan program dalam melaksanakan pemerintahan negara Republik Indonesia.

Ketiga, permohonan juga harus memuat secara rinci mengenai jenis, waktu, dan tempat pelanggaran hukum yang dilakukan oleh Presiden dan/atau Wakil Presiden apabila diduga Presiden dan/atau Wakil Presiden melakukan pelanggaran hukum. Kemudian permohonan juga harus memuat uraian yang jelas mengenai syarat-syarat apa yang tidak dipenuhi dimaksud apaabila diduga Presiden dan/atau Wakil Presiden tidak lagi memenuhi syarat sebagai Presiden dan/ atau Wakil Presiden (Pasal 4 ayat (1) dan (2) PMK No. 21 Tahun 2009).

Keempat, DPR juga wajib melampirkan alat bukti dalam permohonan kepada MK yang berupa risalah dan/atau berita acara proses pengambilan keputusan DPR bahwa pendapat DPR didukung oleh sekurang-kurangnya 2/ 3 dari jumlah anggota DPR yang hadir dalam Sidang Paripurna yang dihadiri oleh sekurang-kurangnya $2 / 3$ dari jumlah anggota; dokumen hasil pelaksanaan fungsi pelaksanaan fungsi pengawasan oleh DPR yang berkaitan langsung dengan materi permohonan; risalah dan/atau berita acara rapat DPR; dan alat-alat bukti mengenai dugaan pelanggaran oleh Presiden dan/atau wakil Presiden yang menjadi dasar pendapat DPR. Alat -alat bukti yang mendukung DPR dapat berupa surat atau tulisan, keterangan saksi, keterangan ahli, keterangan pihakpihak, petunjuk, dan alat bukti lain berupa informasi yang diucapkan, dikirimkan, diterima, atau disimpan secara elektronik dengan alat optik atau yang serupa dengan itu (Pasal 5 PMK No. 21 Tahun 2009).

Registrasi perkara diatur dalam Bab IV dan V PMK No. 21 Tahun 2009 yang secara garis besar simpulkan sebagai berikut. Pertama, begitu permohonan diterima oleh MK maka akan diperiksa oleh Panitera tentang kelengkapan syarat-syarat permohonan. Jika permohonan belum lengkap, maka akan diberitahukan kepada DPR untuk diperbaiki dan/atau dilengkapi dalam jangka waktu paling lama 3 hari kerja sejak pemberitahuan kekuranglengkapan tersebut diterima DPR; kedua, setelah permohonan lengkap akan dicatat dalam Buku Registrasi Perkara Konstitusi (BRPK) oleh panitera. Kemudian panitera mengirimkan satu berkas permohonan yang sudah diregistrasi kepada Presiden dan/atau Wakil Presiden dalam jangka waktu paling lambat 3 hari kerja sejak permohonan dicatat dalam BRPK disertai permintaan tanggapan tertulis atas permohonan yang dimaksud. Tanggapan tertulis Presiden dan/ atau Wakil Presiden dibuat dalam 12 rangkap dan sudah harus diterima oleh Panitera paling lambat satu hari sebelum sidang pertama dimulai; dan ketiga, setelah permohonan lengkap dan Presiden dan/atau Wakil Presiden telah menerima berkas permohonan, maka MK dalam waktu paling lambat 7 hari kerja sejak permohonan diregistrasi oleh Panitera MK menetapkan hari sidang pertama. Penetapan hari sidang diberitahukan kepada pihak-pihak dan diumumkan kepada masyarakat melalui penempelan salinan pemberitahuan di papan pengumuman mahkamah yang khusus digunakan untuk itu (Pasal 7 PMK No. 21 Tahun 2009).

Terkait dengan persidangan diatur dalam Bab $V$ yang secara garis besar menentukan beberapa hal. Pertama, persidangan dilakukan oleh pleno hakim yang sekurang kurangnya dihadiri oleh 7 (tujuh) orang hakim konstitusi; kedua, sidang pleno dipimpin oleh Ketua Mahkamah dan bersifat terbuka untuk umum; ketiga, Sidang Tahap pertama (Sidang Pemeriksaan Pendahuluan) Sidang tahap ini wajib dihadiri oleh Pimpinan DPR dan kuasa hukumnya. Dalam sidang tahap pertama, Presiden dan/ atau Wakil 
Presiden berhak untuk hadir dan apabila tidak dapat hadir maka dapat diwakili oleh kuasa hukumnya. Dalam tahap ini, MK melakukan pemeriksaan atas kelengkapan permohonan dan kejelasan materi permohonan kemudian MK memberikan kesempatan kepada Pimpinan DPR dan/atau kuasa hukumnya untuk melengkapi dan/atau memperbaiki permohonan seketika itu juga. Setelah dilengkapi dan/atau dilakukan perbaikan, MK memerintahkan Pimpinan DPR untuk membacakan dan/ atau menjelaskan permohonannya. Kemudian ketua sidang memberikan kesempatan kepada Presiden dan/atau Wakil Presiden atau kuasa hukumnya untuk mengajukan pertanyaan dalam rangka kejelasan materi permohonan (Pasal 10 PMK No. 21 Tahun 2009).

Keempat, Tahap kedua (Sidang Tanggapan Presiden dan/atau Wakil Presiden). Dalam sidang tahap kedua ini, Presiden dan/atau Wakil Presiden wajib hadir secara pribadi dan dapat didampingi oleh kuasa hukumnya untuk menyampaikan tanggapan terhadap pendapat DPR. Tanggapan Presiden dan/atau Wakil Presiden itu dapat berupa sah atau tidaknya proses pengambilan keputusan pendapat DPR, materi muatan pendapat DPR dan perolehan serta penilaian alat bukti tulis yang diajukan oleh DPR kepada Mahkamah. Dalam tahap ini, MK juga memberikan kesempatan kepada Pimpinan DPR dan/ atau kuasa hukumnya untuk memberikan tanggapan balik (Pasal 12 dan 13 PMK No. 21 Tahun 2009). Kelima, Tahap ketiga (Sidang Pembuktian DPR). Dalam sidang tahap pembuktian DPR wajib membuktikan dalil-dalilnya dengan alat-alat bukti baik berupa surat, keterangan saksi, keterangan ahli, petunjuk dan alat bukti lainnya. Dalam pemeriksaan alat bukti yang diaju-kan oleh DPR, MK memberikan kesempatan kepada Presiden dan/atau Wakil Presiden dan/ atau kuasa hukumnya untuk mengajukan pertanyaan dan/ atau menelitinya (Pasal 14 PMK No. 21 Tahun 2009). Keenam, Tahap keempat adalah Sidang Pembuktian oleh Presiden dan/atau Wakil Presiden. Dalam sidang pembuktian, Presiden dan/atau Wakil Presiden berhak memberikan bantahan terhadap alat-alat bukti yang diajukan oleh DPR dan melakukan pembuktian yang sebaliknya. Macam dan jenis alat bukti yang diajukan oleh Presiden dan/ atau Wakil Presiden pada dasarnya sama dengan macam alat bukti yang diajukan oleh DPR. Dalam sidang ini juga MK memberikan kesempatan kepada DPR dan/atau kuasa hukumnya untuk mengajukan pertanyaan, meminta penjeIasan, dan meneliti alat bukti yang diajukan oleh Presiden dan/atau Wakil Presiden (Pasal 15 PMK No. 21 Tahun 2009). Ketujuh, Tahap kelima (Sidang Kesimpulan pihak-pihak). Dalam sidang tahap kelima setelah sidang-sidang pembuktian oleh Mahkamah dinyatakan cukup. Mahkamah memberi kesempatan baik kepada DPR maupun Presiden dan/atau Wakil Presiden untuk menyampaikan kesimpulan akhir dalam jangka waktu paling lama 14 hari setelah berakhirnya Sidang Tahap empat. Kesimpulan dari DPR dan Presiden dan/atau Wakil Presiden disampaikan secara lisan dan/ atau tertulis.

Kedelapan, sebelum sidang pembacaan putusan atau tahap persidangan keenam di laksanakan, ada mekanisme internal mahkamah untuk mengadakan Rapat Permusyawaratan Hakim (RPH). RPH diselenggarakan untuk mengambil putusan setelah pemeriksaan persidangan oleh Ketua Mahkamah dipandang cukup. RPH dilakukan secara tertutup oleh Pleno Hakim dengan sekurang-kurangnya dihadiri oleh 7 (tujuh) orang Hakim konstitusi. Pengambilan keputusan dalam RPH dilakukan secara musyawarah untuk mufakat. Apabila tidak mencapai mufakat maka keputusan diambil dengan suara terbanyak dan apabila tidak bisa dengan suara terbanyak maka diambil suara terakhir Ketua RPH yang menentukan (Pasal 17 PMK No. 21 Tahun 2009). Kesembilan, sedangkan tahap sidang keenam (Sidang Pengucapan Putusan). Putusan MK terhadap pendapat DPR wajib diputus dalam jangka waktu paling lambat 90 hari sejak permohonan dicatat dalam BRPK. Putusan Mah-kamah yang diputuskan dalam RPH dibacakan dalam sidang Pleno terbuka untuk umum (Pasal 19 ayat (1) dan ayat (2) PMK No. 21 Tahun 2009). Dalam amar putusan, mahkamah dapat menyatakan: Permohonan tidak dapat diterima; membenarkan pendapat DPR apabila Mahkamah berpendapat bahwa Presiden 
dan/atau Wakil Presiden terbukti melakukan pelanggaran hukum berupa pengkhiantan terhadap negara, korupsi, penyuapan, tindak pidana berat lain-nya, atau perbuatan tercela. Dan juga apakah Presiden dan/atau Wakil Presiden tidak lagi memenuhi syarat sebagai Presiden dan/ atau Wakil Presiden berdasar UUD 1945; dan permohonan ditolak apabila pendapat DPR tidak terbukti (Pasal 19 ayat (3) PMK No. 21 Tahun 2009). Kesepuluh, Putusan MK tersebut wajib disampaikan kepada DPR dan Presiden dan/ atau Wakil Presiden dan Putusan MK tersebut bersifat final secara yuridis dan mengikat bagi DPR selaku pihak yang mengajukan permohonan. Kesebelas, Putusan MK yang mengabulkan permohonan DPR tidak menutup kemungkinan diajukannya Presiden dan/atau Wakil Presiden dalam persidangan pidana, perdata dan/ atau tata usaha negara sesuai dengan asas dan hu-kum acara masing-masing (Pasal 20 PMK No. 21 Tahun 2009).

\section{Tindak Lanjut Putusan Mahkamah Konstitusi}

Ada beberapa kemungkinan jika putusan MK tenyata mengabulkan permohonan DPR tentang dugaan bahwa Presiden dan/atau Wakil Presiden telah melakukan pelanggaran hukum berupa pengkhiantan terhadap negara, korupsi, penyuapan, tindak pidana berat lainnya, atau perbuatan tercela dan tidak lagi memenuhi syarat sebagai Presiden dan/atau Wakil Presiden berdasarkan UUD 1945. Paling tindak ada dua kemungkinan yang akan mengikuti putusan MK yang mengabulkan tuntutan DPR, Pertama Presiden dan/atau Wakil Presiden akan menghadapi "pengadilan politik" di depan Sidang Istimewa MPR yang diadakan khusus untuk meminta pertangungjawaban Presiden dan/ atau Wakil Presiden. Kedua, Presiden dan/ atau Wakil Presiden akan menghadapi tuntutan di depan peradilan umum baik terkait dengan tuntutan pidana maupun perdata.

Berdasarkan ketentuan Pasal 7B ayat (5) UUD 1945 hasil amandemen dinyatakan bahwa "Apabila Mahkamah Konstitusi memutus bahwa Presiden dan/atau Wakil Presiden terbukti melakukan pelanggaran hukum berupa penghianatan terhadap negara, korupsi, penyuapan, tin- dak pidana berat lainnya, atau perbuatan tercela; dan/atau terbukti bahwa Presiden dan/ atau Wakil Presiden tidak lagi memenuhi syarat sebagai Presiden dan/atau Wakil Presiden, Dewan Perwakilan Rakyat menyelenggarakan sidang paripurna untuk meneruskan usul pemberhentian Presiden dan/atau Wakil Presiden kepada Maj elis Permusyawaratan Rakyat".

Terhadap usul DPR agar MPR mengadakan sidang paripurna dengan agenda meneruskan usul pemberhentian Presiden dan/atau Wakil Presiden, maka setelah melewati rapat-rapat yang dinamis, panitia ad hoc MPR berhasil merampungkan Rancangan Keputusan MPR RI tentang Peraturan Tatib MPR RI dan Kode Etik Anggota MPR MPR yang disahkan pada tanggal 1 Maret 2010.

Secara garis besar tata cara pemberhentian presiden dan/atau wakil presiden dalam masa jabatannya, diatur pada Bab XVII Pasal 102-105 yakni Pertama, MPR wajib menyelenggarakan Sidang Paripurna MPR untuk memutuskan usul DPR mengenai pemberhentian presiden dan/atau wakil presiden pada masa jabatannya paling lambat 30 hari sejak MPR menerima usulan. Kedua, Usulan DPR harus di lengkapi dengan putusan MK bahwa presiden dan/atau wakil presiden terbukti melakukan pelanggaran hukum berupa pengkhianatan terhadap negara, korupsi, penyuapan, tindak pidana berat lainnya, atau perbuatan tercela; dan/atau terbukti bahwa presiden dan/atau wakil presiden tidak lagi memenuhi syarat sebagai presiden dan/atau wakil presiden. Ketiga Kemudian, MPR mengundang presiden dan/ atau wakil presiden untuk menyampaikan penjelasan yang berkaitan dengan usulan pemberhentiannya dalam Sidang Paripurna MPR. Keempat, Apabila presiden dan/atau wakil presiden tidak hadir untuk menyampaikan penjelasan, MPR tetap mengambil putusan terhadap usulan pemberhentian presiden dan/atau wakil presiden. Kelima, Keputusan MPR atas usul pemberhentian presiden dan/atau wakil presiden harus diambil dalam Sidang Paripurna MPR yang dihadiri sekurang-kurangnya $3 / 4$ dari jumlah anggota dan disetujui sekurang-kurangnya $2 / 3$ 
dari jumlah anggota yang hadir (Pasal 102-105 Peraturan Tata Tertib dan Kode Etik MPR).

Berdasarkan uraian tersebut di atas, maka apabila dikaitkan dengan isi Pasal 102105, khususnya point kelima yang berisi bahwa Keputusan MPR atas usul pemberhentian presiden dan/atau wakil presiden harus diambil dalam Sidang Paripurna MPR yang dihadiri sekurang-kurangnya 3/4 dari jumlah anggota dan disetujui sekurang-kurangnya 2/3 dari jumlah anggota yang hadir, maka sangat mungkin terjadi Putusan MK yang mengabulkan tuntutan DPR terkait dengan dugaan bahwa Presiden dan/atau Wakil Presiden terbukti melakukan pelanggaran hukum berupa penghianatan terhadap negara, korupsi, penyuapan, tindak pidana berat lainnya, atau perbuatan tercela dan/atau terbukti bahwa Presiden dan/atau Wakil Presiden tidak lagi memenuhi syarat sebagai Presiden dan/atau Wakil Presiden, menjadi tidak bermakna manakala Presiden dan/ atau Wakil Presiden dengan kekuasaan dan pengaruhnya dapat mempengaruhi minimal $2 / 3$ dari $3 / 4$ anggota MPR yang hadir untuk tidak menyetuj ui pemberhentian dirinya.

Memperhatikan kemungkinan tersebut, maka ketentuan Pasal 24C ayat (1) UUD 1945 hasil amandemen yang memberikan justifikasi bahwa putusan MK merupakan putusan pada tingkat pertama dan terakhir yang putusannya bersifat final tetapi tidak mengikat, ini sangat mungkin karena memang secara normatif dalam Pasal 24C ayat (1) UUD 1945 hasil amandemen tersebut di atas hanya ditentukan: "Mahkamah Konstitusi berwenang mengadili pada tingkat pertama dan terakhir yang putusannya bersifat final ....", Putusan MK bersifat final hanya mempunyai pengertian bahwa putusan MK tersebut tidak dapat dilakukan upaya banding, persoalan efektivitas dari putusan MK tersebut adalah soal lain, hal ini akan berbeda konsekuensinya jika setelah kata final kemudian diikuti kata dan mengikat, sehingga jika sifat putusan MK adalah final dan mengikat, maka semua komponen bangsa termasuk di dalamnya para penyelenggara Negara mempunyai kewajiban untuk melaksanakan putusan yang dikeluarkan oleh MK.
Untuk menghadirkan putusan MK sebagai putusan hukum yang dapat berlaku efektif, maka ke depan harus dilakukan beberapa langkah Pertama, pemahaman yang baik dari segenap penyelelenggara negara akan arti pentingnya MK sebagai satu-satunya penafsir resmi UUD 1945, dan pemutus dugaan DPR bahwa Presiden dan/atau Wakil Presiden telah melakukan pelanggaran hukum berupa penghianatan terhadap negara, korupsi, penyuapan, tindak pidana berat lainnya, atau perbuatan tercela; dan/atau terbukti bahwa Presiden dan/ atau Wakil Presiden tidak lagi memenuhi syarat sebagai Presiden dan/atau Wakil Presiden, sehingga apapun putusan MK semua elemen bangsa harus menghormati dan melaksanakannya, tanpa harus berwacana untuk menolak dan menilai putusan MK, karena memang putusan MK bukan untuk dinilai tetapi untuk dilaksanakan sebab merupakan putusan pada pengadilan tingkat pertama dan terakhir. Kedua, penyempurnaan UUD 1945 hasil amandemen, khususnya terkait dengan ini, maka ketentuan Pasal 24C ayat (1) dibelakang kata final ditambahkan kata dan mengikat.

Konsekuensi kedua dari putusan MK yang mengabulkan dugaan DPR yang memungkinkan Presiden dan/atau Wakil Presiden di hadapkan dalam sidang peradilan umum tentunya akan berlaku Kitab Undang-Undang Hukum Acara Pidana (KUHAP), hal ini sebagaimana diatur daIam PMK No. 21 Tahun 2009 yang menentukan bahwa putusan MK yang mengabulakan permohonan DPR tidak menutup kemungkinan di ajukannya Presiden dan/atau Wakil Presiden dalam persidangan pidana, perdata dan/atau tata usaha negara sesuai dengan asas dan hukum acara masing-masing.

\section{Penutup \\ Simpulan}

Berdasarkan uraian tersebut di atas, maka dapat disimpulkan bahwa keberadaan MK sebagai salah satu pelaku kekuasaan kehakiman yang mempunyai wewenang mengadili atas pendapat DPR bahwa Presiden dan/atau wakil Presiden telah melakukan pelanggaran hukum berupa penghianatan kepada negara, korupsi, 
penyuapan, tindak pidana berat lainnya, atau perbuatan tercela; dan/atau pendapat bahwa Presiden dan/atau Wakil Presiden tidak lagi memenuhi syarat sebagai Presiden dan/atau Wakil Presiden adalah merupakan upaya normatif bangsa Indonesia untuk menghindari terulangnya alasan pemberhentian Presiden dan/ atau Wakil Presiden yang hanya didasarkan kepada fitnah dan sangkaan yang hanya memuaskan kepentingan politik para elit politik.

\section{Saran}

Untuk memperkuat putusan MK terkait dengan pendapat DPR bahwa Presiden dan/atau wakil Presiden telah melakukan pelanggaran hukum berupa penghianatan kepada negara, korupsi, penyuapan, tindak pidana berat lainnya, atau perbuatan tercela; dan/atau pendapat bahwa Presiden dan/atau Wakil Presiden tidak lagi memenuhi syarat sebagai Presiden dan/atau Wakil Presiden, diperlukan kategasan bahwa putusan tersebut harus dilaksanakan oleh para pihak, dan MPR hanya dalam kapasitas untuk melaksankan putusan MK tersebut.

Demikian paparan ini, penulis menyadari akan keterbatasan kemampuan sehingga penulisan ini tidak "kalis" dari kemungkinan kesalahan baik yang bersifat substansi maupun redaksional, oleh karenanya masukan. Kritik dan bakan sanggahan dari para pembaca, akan sangat bermanfaat untuk perbaikan di masa yang akan datang. Akhirnya hanya kepada Allah SWT tempat berserah diri.

\section{Daftar Pustaka}

Anonimous. Maret 2001. Catatan CatatanCatatan Terhadap Hasil Rumusan Amandemen Pertama Dan Kedua, Jakarta: Konsorsium Reformasi Hukum Nasional (KRHN);

MD, Moh. Mahfud. "Perubahan UUD 1945 dan Perkembangan Hukum Tata Negara", J urnal Hukum J urisdictie. 2010;

Erwiningsing, Winahyu. "Mahkamah Konstitusi (Telaah Terhadap Putusan Mahkamah Konstitusi dan Fungsi Mahkamah Konstitusi dalam Reformasi Hukum". Jurnal Ilmu Hukum. Vol. 9 No. 1. Tahun 2006. Surakarta: Fakultas Hukum UMS;
Fathudin, Usef. "UUD 1945 dan Konstitusi Amerika Serikat : Studi Komparatif". SPEKTRA J urnal IImu-IImu Sosial. Vol.1 No. 1. Tahun 2010. Jakarta: Universitas Islam As-Syafi' iyah;

Fauzan, Muhammad. "Pembubaran Partai Politik (Tinjauan Tentang Kewenangan Mahkamah Konstitusi untuk Memutuskan Pembubaran Partai Politik Berasarkan Pasal 24C ayat (1) Undang Undang Dasar 1945)". Jurnal Konstitusi Vol. 1 No. 1. Agustus 2008. Malang: PKKKD FH UMM;

"Terobosan Mahkamah Konstitusi (Analisis Tentang Putusan MK No. 41/ PHPU. D-VI/ 2008)". J urnal Dinamika Hukum Vol. 9 No. 1. J anuari 2009. Purwokerto: Fakultas Hukum UNSOED;

-.-.-.-. “Eksistensi Komisi Yudisial Dalam Struktur Ketatanegaraan Republik Indonesia dan Yang Seharusnya Diatur Dalam Peraturan Perundang-undangan". J urnal Dinamika Hukum Vol. 8 No. 1. Tahun 2008 Purwokerto: Fakultas Hukum UNSOED;

Marjuki, Laica. "Membangunan Undang-undang yang Idial". Jurnal Legislasi Indonesia. Vol. 4 No. 2. Tahun 2007. Jakarta: Departemen Hukum dan Ham;

Murtopo, Ali. "Peranan mahkamah Konstitusi Dalam Bidang Impeachment Presiden Di Indonesia, Jurnal IImu Hukum Novelty. Vol. 3 No. 1. Tahun 2006;

Sapuan. 2010. Impeachment Presiden. Purwokerto: STAIN Press;

Syahrizal, Ahmad. "Problematik Implementasi Putusan MK". J urnal Konstitusi Vol. 4 No. 1. Maret 2007. J akarta: MKRI;

Thalib, Abdul Rasyid. 2006. Wewenang Mahkamah Konstitusi dan Implikasinya dalam Sistem Ketatanegaraan Indonesia. Bandung: Citra Aditya Bakti;

Watiah dan Kusriyah. "Tinjauan Yuridis Hubungan Lembaga Negara antara DPD dengan DPR Dalam Sistem Bicameral di Indonesia". J urnal Hukum Khaira Ummah Vol. 3 No. 2. September 2008. Semarang: MIH UNISSULA;

Yudho, Winarno. Dkk. 2005. Mekanisme Impeachment dan Hukum Acara Mahkamah Konstitusi. Jakarta: Konrad Adenauer Stiftung dan Pusat Penelitian dan Pengkajian Sekretariat Jenderal dan Kepaniteraan Mahkamah Konstitusi Republik Indonesia. 